\title{
A Postcolonial Education: Using End of Empire Autobiographies to Introduce Postcolonial Studies
}

\author{
Astrid Rasch
}

University of Copenhagen

\section{ABSTRACT IN ENGLISH}

This article reviews the experiences with teaching Jill Ker Conway's autobiography The Road From Coorain (1989). The two weeks of lectures and seminars were part of a six-week introductory course to Postcolonial Studies for first year undergraduates at the English Department at the University of Copenhagen. The lectures provided a theoretical and historical framework and the seminars consisted of close reading and discussion of the texts. I describe how four concepts which are central to postcolonial theory, discourse, identity, representation and agency, were used in readings of the text. The article takes its point of departure in discussions about the post-imperial time of writing, the creation of individual identity in dialogue with one's context, the ambiguous representation of Aboriginal people and the agency involved in writing a life story which goes against the expected narrative. I discuss the difficulties of the course and provide recommendations for improvements for future iterations of the course. Despite occasional difficulties, I argue that autobiographies are useful sources for an introduction to Postcolonial Studies.

\section{ABSTRACT IN DANISH}

Denne artikel beskriver erfaringerne med at undervise i Jill Ker Conways The Road From Coorain (1989). Det to ugers undervisningsforløb med forelæsninger og seminartimer var del af et seks-ugers introduktionskursus i postkoloniale studier for førsteårsstuderende ved Engelsk på Københavns Universitet. Forelæsningerne satte de teoretiske og historiske rammer, og seminartimerne bestod af nærlæsning og diskussion af teksterne. Jeg beskriver, hvordan fire 
begreber, som er centrale for postkolonial teori, diskurs, identitet, repræsentation og agens, blev brugt i læsningerne af teksten. Artiklen tager udgangspunkt i diskussioner om det post-imperiale skriveøjeblik, konstruktionen af individuel identitet i dialog med ens omgivelser, den tvetydige repræsentation af aborigine mennesker og den agens, som er involveret $i$ at skrive en livshistorie, som går imod det forventede narrativ. Jeg diskuterer udfordringerne ved kurset og kommer med anbefalinger til forbedringer til fremtidige udgaver af kurset. Trods lejlighedsvise problemer argumenterer jeg for, at selvbiografier er brugbare kilder til en introduktion til postkoloniale studier.

Keywords: Postcolonial studies, autobiography, teaching, discourse

\section{INTRODUCTION}

To understand a new field of knowledge, one must grasp its language, how it uses specific concepts to engage with the world. Introducing Postcolonial Studies, a number of texts may be used to show students the applicability of this new vocabulary, and among these are autobiographies. In the six week introductory course to Postcolonial Studies for first-year undergraduates studying English at the University of Copenhagen that this article treats, I sought with my co-teacher, Associate Professor Ulla Rahbek to develop a "tool kit" with the students, so that they might use terms like discourse, identity, representation and agency to access and understand postcolonial texts. While there were some difficulties involved, I will argue here for the usefulness of autobiographies in this context.

In the first two weeks, we introduced the students to these and other concepts and they close read short texts like extracts from Frantz Fanon's works and poems by Derek Walcott and Wole Soyinka, applying the concepts they had just learned. During the next two weeks, they were engaged in reading two autobiographies, Australian Jill Ker Conway's The Road From Coorain (1989) and extracts from Barbadian Austin Clarke's Growing Up Stupid Under the Union Jack (1980). The two final weeks of the course were focused on Joseph Conrad's Heart of Darkness. Here, I will focus on the use of Ker Conway's autobiography. The structure of the teaching was one-hour lectures which gave a background understanding of the historical and theoretical context and two-hour seminars with close readings in groups and discussions in class. While my co-teacher gave the lectures and taught all classes the two final weeks, I did the same for the two weeks on autobiographies.

The weeks on autobiography provided the students with their first chance to try out their new vocabulary on a book-length work. At the 
same time, the inclusion of a text by a white Australian complicated the picture of what constitutes postcolonial experience, while Ker Conway's focus on women's issues brought to the students' attention the gender aspects of discussions about discourse, identity, representation and agency. In the following, I will use these four concepts as my point of departure to describe some of the discussions we had in class and how the students responded to them. Here, the focus will be on discourse and the post-imperial time of writing, the creation of individual identity in dialogue with one's context, the ambiguous representation of Aboriginal people and the agency involved in writing a life story which goes against the expected narrative. I will also discuss the difficulties of the course and provide recommendations for improvements for future iterations of the course. I will conclude by addressing the usefulness of autobiographies for an introduction to Postcolonial Studies.

\section{DISCOURSE}

An understanding of how discourses constitute and produce our sense of reality is central to postcolonial researchers (McLeod 2000, 18-19). We examine the power structures that shape colonial discourses, how they have affected everything from world views to individual identities of colonisers and colonised alike, and how postcolonial texts may be read as resistance to hegemonic discourses. One of the reasons why I selected Ker Conway and Clarke for comparison is that they were both written after the unravelling of the British Empire but deal with the authors' childhood and youth before the loosening of imperial ties. This means that they are good case studies for how the imperialist discourse is represented when written about in a post-imperial light. Both authors take the imperialist discourse prevalent at the time of their growing up and turn it against itself, writing at a time when discourses of British superiority had been discredited. They write about the alienating experience of being brought up to think highly of a distant culture and lowly of their own.

Besides demonstrating the destructive effects of colonial discourses, the argument that I sought to convey to the students was that one of the reasons for the authors' vehement rejection of their imperial upbringing is their post-imperial point of view. I wanted to show that the discrepancy between the discourses of their youth and that of their adulthood accentuates and makes them reflect critically upon the estranging effects of colonial discourse. In a text written after the breaking up of the imperial bonds but about a time of high imperialist sentiment, it is relevant to question, for instance, Ker Conway's descriptions of the numerous instances of her personal disaffection with the Empire and her growing desire to look 
at the world from an Australian perspective rather than an imperial one (Conway 1998, 67-68, 128-134, 181-183, 201-211). I tried to make the students reflect critically upon whether this narrative trajectory might at least partly be the result of rationalisation after the fact, a product of the position of Australia at the time she wrote her autobiography as much as accurate memories of childhood scepticism against Empire.

While some students developed a critical sense of distinguishing the narrated moment from the moment of narration, for other first-year students, this was clearly a discussion at a level of complexity which they did not fully grasp. Thus, some of their readings in class and in their exams demonstrated a tendency to read the events of the text as though the protagonist were on the same temporal or experiential level as that of the author and narrator. For instance, they might take at face value Ker Conway's statements about her youthful rejection of British imperialism rather than interrogating to what extent this may be an effect of postcolonial hindsight. While the students may be familiar with the idea of the unreliable narrator, the form of the autobiography seems to dispel this critical sense and cause them to think that whatever is put forth must be the truth because author and protagonist share a name.

Yet in spite of these difficulties, the texts worked well in giving the students an idea of the alienating effects of imperialist discourse. While they did not all grasp the extent to which the authors were also responding to postcolonial conditions and hence perhaps highlighting the negative aspects of their colonial past, they were all impressed with the childhood experiences they portrayed. Thus, life writing like these texts could serve the double purpose of acting for some students merely as a witness account, providing first-hand insights into colonial lives, while for others demonstrating also the effects of changing discourses as they developed a sensitivity to difference in narrated and narrating selves.

\section{IDENTITY}

A shared preoccupation of Postcolonial and Auto/biography Studies is the dialogical construction of identity, how our selves are "relational", shaped in dialogue with our immediate social surroundings as well as societal discourses (Eakin 1990, 43-98; Moore-Gilbert 2009, 17-33; Taylor 1995, 57-66). The students were encouraged to consider the constitutive role of society and social relations in the formation of individual identity and how the individual navigates between different belongings.

We looked at the many different groups that Ker Conway identifies with and how she negotiates these various attachments. On the blackboard, 
we gathered identifications like "woman", "intellectual", "bush settler", "Australian", "elite", "historian" and "white". We then discussed how she uses some of these identifications to counterbalance others. In this context, we considered the importance of the audience, as her autobiography was published while she was living in the US. Ker Conway writes about Australian nature for outsiders who do not know its natural scene but who are familiar with Western culture (Conway 1998, 5-6). Her narrative partly conforms to a pattern of "the American dream", going through much hardship and creating one's own happiness despite the odds. At the same time, she responds to the ideal of a "real Australian" as a bush worker, not an intellectual (White 1981, 76-77). In this respect, her upper middle class background seems at times an inconvenience which she counteracts by repeated references to her experience with hard work. In particular, she uses her bush upbringing to justify her attachment to the land and mitigate the elitism implied in her parents' wealth and her own education. Through stories of working with the shearers at her parents' farm and her appreciation of outback nature, she signals that she knows hard labour, making her at once a "truer" Australian and more worthy of American respect (Conway 1981, 41-46; 58; 222-224).

It was clear, then, that Ker Conway's identity is not described in isolation but in constant dialogue with her immediate social and societal surroundings, past and present. Positioning herself in a field of past discourses of national identity, an American audience in the present and her close relationship with work and workers, Ker Conway establishes a "relational self" and creates a precarious space for herself within the antiintellectualism of the Australian identity narrative and the adoration of the "self-made man" in American society.

\section{REPRESENTATION}

One of the issues that preoccupy postcolonial theorists is representation, both in the sense of depiction and of standing for something. We are interested in who represents whom, what people are made to symbolise and whether they have the agency to decide how they want to be represented. In the first weeks, we had discussed how Fanon writes from a firstperson point of view about the experience of "crushing objecthood" of being reduced to an object through other people's representation, made to stand for all of black people and associated with all the stereotypes about black people circulated in metropolitan France (Fanon 109). We had also discussed how he resists such representations by claiming a different identity, representing himself not as object but subject. 
Having become thus attuned in the first few weeks to questions of representation and race, the students were able to critically engage with Ker Conway's representation of indigenous Australians. Aboriginal people are shadowy and marginal figures in the autobiography. These voiceless characters appear only four times in the narrative and seem all but written out of the history of Australia with which Ker Conway presents us. It could be argued that Ker Conway invokes their presence in a rather self-serving manner, paying lip service to an awareness of indigenous entitlement which was increasing at the time of her writing, but without evincing a deeper recognition of their continuing presence and humanity. The two half-Aboriginal workers on her parents' farm are described only in passing and in rather stereotypical terms, referring to the "aboriginal need" of one of them "to go "on walkabout" and they are mentioned only as "friends" when it suits the narrative and moral purpose of the story (Conway 1998, 63, 194). Thus, when Ker Conway describes how she failed to get a job because she was a woman, she says that this made her feel a sudden "kinship with black people": "As it came home to me that my sex had rendered my merits invisible, I thought differently about the way we had taken over the aborigines' land" (Conway 1998, 191-192).

When we discussed this passage in class, some of the students were indignant that Ker Conway compares her own experience of discrimination because of her gender with that of the dispossession of Aboriginal people as they saw a difference in magnitude between not getting a job and being forced off one's land (a difference which Ker Conway herself recognises). Some argued that she only seems to use her relationship to the Aboriginal workers on her parents' farm when it is convenient to claim friendship with Australia's indigenous population (Conway 194).

Other students, however, applauded Ker Conway's attempts to connect with Australia's indigenous population through the image of the nardoo stones of her family home which she problematises as her narrated awareness of dispossession increases. Thus, the "golden image from childhood" of her parents resting their feet on the Aboriginal grinding stones is described as having gained a new dimension as she saw how their feet had been "resting on the tribal treasures of black people, things our ancestors had felt free to possess because of the aborigines' blackness. They and I were participants in the process by which those black people's land and rights had been taken away from them" (Conway 1998, 191192). Taking a pragmatic middle-ground view, one student commented that the fact that Ker Conway largely omits Aboriginal people yet signals a growing sympathy for their cause is perhaps a fairly honest representation of what her actual experience with Aboriginal people had been, as 
she would have had little interaction with the indigenous population. Thus, while her representation of Aboriginal people is flat though sympathetic, her representation of her own experience may be accurate and hence offers insight into the marginal position of Aboriginal people in white settler consciousness. As these examples demonstrate, white settler narratives can be used for a lively discussion about the ambiguous representation of the colonised.

\section{AGENCY}

But, of course, it is not only the representation of others, but also the representation of self which is interesting when studying postcolonial autobiographies. Here the concept of agency, the power to initiate action and to self-represent, to which the students had been introduced in the weeks previously in a race context, was useful (Ashcroft, Griffiths, and Tiffin 2007, 6-7). While we took a critical view of Ker Conway's identification with indigenous people through her experience of gender prejudice, we also discussed some of the very real gender issues that Ker Conway addresses. We discussed how Ker Conway claims agency as an intellectual woman both in the instances she narrates and also in the very writing of her autobiography. She sets herself up against an existing discourse of what a woman ought to be and tells the story of how she came to claim another identity for herself, thereby claiming agency and doing so once again at the moment of writing by giving voice to that different account of what a woman's life might be like.

We read Ker Conway's narrative as the story of finding a vocation and studied the ways in which the emergence of her interest as a feminist historian is woven into the narrative. She describes the many spoken and unspoken expectations that a woman marry rather than work, as intellectual women were "laughable", and how she had decided not to try to "hide my anomalous female self" despite societal expectations that work as a scholar was "unfeminine" (Conway 1998, 146; 196; 219). The writing of her autobiography after many years of successful career is the ultimate performance of her agency as she represents her own identity and how she refused to be confined by societal discourses on women.

The debate on gender was integrated with a discussion of (post)colonial experience as we discussed the conflation of gender and national identity implied in the masculine bush ethos of Australian settler identity. We studied how Ker Conway represents the stoicism and gender roles implied in this frontier mythology as an emotional desert to match the heart of the Australian continent. In her autobiography, Ker Conway 
demonstrates that she is able to be a proud Australian with a profound attachment to the land without buying into the male-dominated image of what an Australian ought to be like.

\section{DIFFICULTIES AND RECOMMENDATIONS}

An issue that arose during the teaching concerns some students' difficulty with grasping the distance between the moment of writing and the past narrated and the changes in discourse that have occurred in between. This problem is understandable as it is difficult to determine whether any given representation is a transparent rendition of what the past was like or whether it is a result of the moment the author sits down to write. This issue relates to a central concern of Auto/biography Studies and of narratology, namely the relationship between the author, the narrator and the protagonist (Cohn 1999, 31; Genette 1980, 1989, 212-262; Lejeune $11)$. While it is an issue I already spent much time on making the students aware of, I believe that the vocabulary from autobiography theory might help clarify the narrative situation. In the future, I would consider using autobiographies as an entry point into sensitising the students to the complexities of the author-narrator-protagonist relationship, thus furnishing them with an attention which will stand them in good stead in their literary studies more generally.

Growing up in a country which has all but forgotten its history as a colonial power, Danish students are not familiar with the issues debated by postcolonial theorists and authors. One of the purposes of including an Australian text was to give the students a sense of the diversity of colonial experience in settler dominions and colonies, as well as to show some of the similarities across the board. As the above discussion of the representation of Aboriginal people demonstrates, the students recognised the position of power that white settlers hold in Australia. However, our discussions of the national awakening in Ker Conway and her rejection of the Empire made some of the students read Ker Conway as colonised rather than coloniser. This has subsequently made me conscious of the need to provide the students with better tools for reading such texts "against the grain". (McLeod 2000, 24; Said 1993, 66-67). Such readings would improve their awareness that a postcolonial text need not be read as expressing the voice of the oppressed. Despite these confusions, I believe the inclusion of Ker Conway gave the students valuable insight into another aspect of postcolonial responses than the ones they had encountered in the first two weeks of the course, namely settler colonial ones with all the ambiguities they contain. 


\section{CONCLUSION}

Autobiographies offer a unique source for discussions about the construction and representation of identity in which the students may consider both the social influences that shape individual identity and the question of how the author chooses to represent his/her identity. In addition, students may consider how other groups are represented by the author and how such representations are discursive products. While discourse is a complex concept that first year students may struggle with, it is one which will help their reading of other texts, not just postcolonial ones. The changing discourses of end-of-empire autobiographies make them interesting case studies through which to try to understand how discourses mediate our experience of being in the world. In spite of the difficulties with grasping some of the complexities of postcolonial theory and the narrative situation in these texts - difficulties which could be countered through teacher awareness of what issues need clarification - the use of autobiographies for an introductory course on Postcolonial Studies has definitely proven worthwhile and is most certainly recommended.

\section{WORKS CITED}

Ashcroft, Bill, Gareth Griffiths, and Helen Tiffin. Post-Colonial Studies: The Key Concepts. 2nd ed. New York: Routledge, 2007.

Cohn, Dorrit. The Distinction of Fiction. Baltimore: Johns Hopkins University Press, 1999.

Conrad, Joseph. Heart of Darkness: An Authoritative Text, Backgrounds and Sources, Criticism. Ed. Robert Kimbrough. New York: Norton, 1988.

Conway, Jill K. The Road From Coorain. London: Vintage Books, 1998.

Eakin, Paul John. How Our Lives Become Stories: Making Selves. Ithaca, NY: Cornell University Press, 1999.

Fanon, Frantz. "Concerning Violence." Ed. Jean-Paul Sartre and Constance Farrington. The Wretched of the Earth. New York: Grove Press, 1965. 27-41.

Fanon, Frantz. "The Fact of Blackness." Black Skin, White Masks. New York: Grove Press, 2008, $109-123$.

Genette, Gérard. Narrative Discourse: An Essay in Method. Ithaca, NY: Cornell University Press, 1980.

Lejeune, Philippe. "The Autobiographical Pact." Ed. Paul John Eakin. On Autobiography. Minneapolis: University of Minnesota Press, 1989. 3-30.

McLeod, John. Beginning Postcolonialism. Manchester, UK; New York: Manchester University Press, 2000.

Moore-Gilbert, B. J. Postcolonial Life-Writing: Culture, Politics and Self-Representation. London; New York: Routledge, 2009.

Said, Edward W. Culture and Imperialism. New York: Knopf, 1993.

Soyinka, Wole. "Telephone Conversation." Eds. Gerald Moore and Ulli Beier. Modern Poetry from Africa. Harmondsworth: Penguin Books, 1963.

Taylor, Charles. "The Dialogical Self." Eds. Robert F. Goodman and Walter R. Fisher. Rethinking Knowledge: Reflections Across the Disciplines. Albany, NY: SUNY Press, 1995. 57-66. 
Walcott, Derek. "A Far Cry from Africa." Ed. Edward Baugh. Selected Poems. New York: Farrar, Straus and Giroux, 2014.

White, Richard. Inventing Australia: Images and Identity 1688-1980. Sydney: Allen \& Unwin, 1981.

\section{ABOUT THE AUTHOR}

Astrid Rasch is a PhD fellow in English at the University of Copenhagen as part of the Velux-funded research project Embers of Empire. Her PhD project examines autobiographies from various parts of the former British Empire by people who have lived through its dissolution to study how they make sense of that event as well as of their pre-decolonisation lives. She has taught courses on contemporary Australia, on the metropolitan repercussions of the end of the British Empire and on Postcolonial Studies. She holds an MA in English from the University of Copenhagen from 2012. 